\title{
OPTIMALISASI KEBIJAKAN KETENAGAKERJAAN DALAM MENGHADAPI MASYARAKAT EKONOMI ASEAN 2015
}

(The Optimization of Employment Policies in Facing The ASEAN Economic Community 2015)

\author{
Muhammad Fadli \\ Kantor Wilayah Kementerian Hukum dan HAM Sulawesi Selatan \\ Email: fadlilaw@gmail.com
}

Naskah diterima: 21 Mei 2014; revisi: 20 Agustus 2014; disetujui: 22 Agustus 2014

\begin{abstract}
Abstrak
Masyarakat Ekonomi ASEAN adalah salah satu pilar pembentukan Komunitas ASEAN dan merupakan bentuk integrasi ekonomi regional yang mulai di berlakukan pada tahun 2015. Pemberlakuan tersebut akan menjadikan ASEAN sebagai pasar tunggal dan basis produksi dimana terjadi arus barang, jasa, investasi dan tenaga terampil yang bebas serta aliran modal yang bebas antar-negara di kawasan ASEAN. Arus bebas tenaga kerja terampil tersebut harus dimanfaatkan oleh Indonesia sebagai peluang dalam menyerap tenaga kerja dan mengurangi pengangguran. Hal yang menjadi permasalahan adalah bagaimanakah kebijakan pemerintah dalam bidang ketenagakerjaan dalam mempersiapkan tenaga kerja terampil menghadapi Masyarakat Ekonomi ASEAN 2015. Dengan menggunakan metode penelitian yuridis normatif dapat disimpulkan bahwa terdapat berbagai kebijakan dalam bidang ketenagakerjaan yang mendukung terciptanya Sumber Daya Manusia yang berkualitas atau tenaga kerja terampil. Maka dari itu, Undang-Undang Nomor 13 Tahun 2003 tentang Ketenagakerjaan dan berbagai kebijakan lain yang mengamanatkan pemberian pelatihan kerja serta pembentukan Badan Nasional Sertifikasi Profesi yang bertugas memberikan sertifikasi kompetensi kerja harus dioptimalkan, guna mempersiapkan tenaga kerja terampil, berkualitas dan berdaya saing serta diakui oleh negara ASEAN lainnya dalam menghadapi Masyarakat Ekonomi ASEAN 2015.
\end{abstract}

Kata Kunci: optimalisasi, kebijakan, tenaga kerja

\section{Abstract}

ASEAN Economic Community is one of the pillars of the establishment of the ASEAN Community which formally as a form of regional economic integration that will enter into force by 2015. This enforcement will make ASEAN as a single market and production based where there are flow of goods, services, investment and skilled labor that is free and free capital flows among ASEAN member countries. Free flow of skilled labor should be used by Indonesia as an opportunity to absorb employment and reducing unemployment. The issue of this subject is how the government policy in the field of labor in preparing skilled labour in facing the ASEAN Economic Community 2015. By using the method of juridical normative research can be concluded that there are a variety of employment policies supporting the creation of high quality human resources or skilled labor.Thus, Law of Republic of Indonesia Number 13 year 2003 on Employment and another regulations that mandate the provision of vocational training and the establishment of the National Professional Certification which in charge of certifying the competence of work must be optimized in order to prepare skilled labour, high quality and having competitiveness and recognized by the other ASEAN countries in facing the ASEAN Economic Community 2015.

Keywords: optimization, policy, labor 


\section{A. Pendahuluan}

ASEAN Economic Community atau Masyarakat Ekonomi ASEAN (MEA) merupakan bentuk integrasi ekonomi regional yang mulai diberlakukan dan ditargetkan pencapaiannya pada tahun 2015. Dengan pencapaian tersebut, ASEAN akan menjadi pasar tunggal dan basis produksi dimana terjadi arus barang, jasa, investasi dan tenaga terampil yang bebas serta aliran modal yang bebas. Adanya aliran komoditi dan faktor produksi tersebut diharapkan membawa ASEAN menjadi kawasan yang makmur dan kompetitif dengan perkembangan ekonomi yang merata, serta menurunnya tingkat kemiskinan dan perbedaan sosial-ekonomi di kawasan ASEAN. Peluang integrasi ekonomi regional tersebut harus dapat dimanfaatkan dengan semaksimal mungkin oleh Indonesia. Hal tersebut mengingat jumlah populasi, luas dan letak geografi, dan nilai Produk Domestik Bruto (PDB) terbesar di ASEAN harus menjadi aset agar Indonesia bisa menjadi pemain besar dalam ASEAN Economic Community.

Krisis ekonomi yang melanda kusususnya kawasan Asia Tenggara mendorong Kepala Negara anggota ASEAN menyepakati pembentukan Komunitas ASEAN (ASEAN Community) dalam bidang Keamanan Politik (ASEAN Political-Security Community), Ekonomi (ASEANEconomic Community), dan Sosial Budaya ASEAN (ASEAN Socio-Culture Community) yang dikenal dengan Bali Concord II dideklarasikan di Bali pada Oktober 2003. Selanjutnya Peringatan 40 tahun berdirinya ASEAN, bentuk kerja sama regional semakin diperkuat dan bertransformasi dengan ditandatanganinya Piagam ASEAN (ASEAN Charter) pada KTT ASEAN ke-13 pada tanggal 20 November 2007 di Singapura. Para Kepala Negara atau Pemerintahan NegaraNegara Anggota ASEAN yang berkumpul di
Singapura dalam rangka memperingati 40 tahun pendirian ASEAN menyepakati Piagam ASEAN atau ASEAN Charter. Kesepakatan dan penandatanganan Piagam ASEAN tersebut bertujuan untuk mengintensifkan pembentukan komunitas melalui peningkatan kerja sama dan integrasi kawasan melalui pembentukan Komunitas ASEAN. Adapun salah satu pilar Komunitas ASEAN yaitu, pembentukan Komunitas Ekonomi ASEAN sebagaimana Deklarasi Bali Concord II, dimana salah satu tujuan kerjasama dan integrasi kawasan tersebut dalam bidang ekonomi diatur dalam Bab I, Pasal 1 angka 5 dan 6 Piagam ASEAN, sebagai berikut:

"To create a single market and production base wich is stable, prosperous, highly competitive and economically integrated with effective facilitation for trade and investment in wich there is free flow of goods, services and investment; facilitated movement of business persons, professionals, talents and labor; and freer of capital, and to alleviate poverty and narrow the development gap within ASEAN trough mutual assistance and cooperation."

Berdasarkan ketentuan pasal tersebut, diketahui bahwa negara-negara anggota ASEAN bertekad untuk menciptakan pasar tunggal dan basis produksi yang stabil, makmur, sangat kompetitif, dan terintegrasi secara ekonomis melalui fasilitasi yang efektif untuk perdagangan dan investasi yang di dalamnya terdapat arus lalu lintas barang, jasa-jasa dan investasi yang bebas; terfasilitasinya pergerakan pelaku usaha, pekerja profesional, pekerja berbakat dan buruh; dan arus modal yang lebih bebas; mengurangi kemiskinan dan mempersempit kesenjangan pembangunan di ASEAN melalui bantuan dan kerja sama timbal balik. Bersamaan dengan penandatanganan Piagam ASEAN, cetak biru yang merupakan arah panduan Masyarakat 
Ekonomi ASEAN (MEA) dan jadwal strategis tentang waktu dan tahapan pencapaian dari masing-masing pilar juga disepakati. Pemberlakuan cetak biru tersebut ditindaklanjuti Pemerintah Indoesia dengan dikeluarkannya Instruksi Presiden Republik Indonesia Nomor 11 Tahun 2011 tentang Pelaksanaan Komitmen Cetak Biru Masyarakat Ekonomi Association of Southeast Asian Nations Tahun 2011. Hal tersebut merupakan bukti dari keseriusan Pemerintah Indonesia dalam rangka pelaksanaan Komitmen Cetak Biru Masyarakat Ekonomi Association of Southeast Asian Nations (ASEAN Economic Community-AEC) Tahun 2011 untuk mendukung peningkatan iklim investasi dan perdagangan serta meningkatkan daya saing nasional.

Cetak Biru Masyarakat Ekonomi ASEAN atau AEC Blueprint merupakan pedoman bagi negara-negara Anggota ASEAN dalam mewujudkan AEC 2015. AEC memuat empat pilar utama yaitu: 1) ASEAN sebagai pasar tunggal dan berbasis produksi tunggal yang didukung dengan elemen aliran bebas barang, jasa, investasi, tenaga kerja terdidik dan aliran modal yang lebih bebas, 2) ASEAN sebagai kawasan dengan daya saing ekonomi tinggi dengan elemen peraturan kompetisi, perlindungan konsumen, hak atas kekayaan intelektual, pengembangan infrastruktur, perpajakan, dan e-commerce, 3) ASEAN sebagai kawasan dengan pengembangan ekonomi yang merata dengan elemen pengembangan usaha kecil dan menengah dan prakarsa integrasi ASEAN untuk negara-negara CMLV (Cambodia, Myanmar, Laos, dan Vietnam), dan 4) ASEAN sebagai kawasan yang terintegrasi secara penuh dengan perekonomian global dengan elemen pendekatan yang koheren dalam hubungan ekonomi di luar kawasan, dan meningkatkan peran serta dalam jejaring produksi global.

Integrasi ekonomi tersebut memberi berbagai peluang dan tantangan yang akan dihadapi oleh Indonesia. Salah satu diantaranya adalah arus bebas tenaga kerja terampil atau terdidik. Hal ini membutuhkan perhatian yang serius bagi pemerintah Indonesia. Mengingat Indonesia memiliki aset Sumber Daya Manusia (SDM) yang begitu melimpah. Berdasarkan hasil proyeksi Badan Pusat Statisitik (BPS), jumlah penduduk Indonesia pada Tahun 2013 sebanyak 248,8 juta orang dengan jumlah angkatan kerja di Indonesia pada Februari 2014 mencapai 125,3 juta orang.

$\mathrm{Hal}$ tersebut merupakan peluang sekaligus tantangan berat bagi Indonesia. Pemerintah maupun seluruh stakeholder harus mempersiapkan diri dalam menghadapi pengaruh arus bebas tenaga kerja tersebut, agar momentum ini dapat dimanfaatkan oleh pemerintah maupun masyarakat sebagai peluang dalam mengurangi pengangguran dan memanfaatkan berbagai lapangan kerja baik di dalam maupun di luar negeri bukan menjadi penonton di negeri sendiri dan menjadi pihak yang dirugikan jika lapangan kerja dalam negeri lebih banyak menyerap tenaga kerja terampil dari luar negeri.

Peran pemerintah sebagai regulator menjadi sangat penting guna melindungi tenaga kerja yangadadidalamnegeri.Bidangketenagakerjaan merupakan bagian dari tugas dan fungsi Kementerian Tenaga Kerja dan Transmigrasi terbagi menjadi empat besaran, yakni: (a) Pelatihan keterampilan kerja, (2) Penempatan tenaga kerja, (3) Hubungan industrial dan jaminan sosial tenaga kerja, dan (4) Pengawasan ketenagakerjaan. Sebagai sebuah program yang berkaitan langsung dengan pengembangan 
Sumber Daya Manusia (SDM), lebih-lebih dalam situasi dimana SDM Indonesia belum menjadi modal sumber daya yang kompeten, kondisi yang dialami oleh program pelatihan keterampilan kerja justru memprihatinkan. Pelatihan belum mendapat posisi penting dalam pembangunan ketenagakerjaan nasional dan belum menjadi gawe nasional.

Hal ini perlu menjadi perhatian utama pemerintah dalam hal ini Kementerian Tenaga Kerja dan Transmigrasi, mengingat tujuan Pemerintah Negara Republik Indonesia, yaitu melindungi segenap bangsa dan seluruh tumpah darah Indonesia, memajukan kesejahteraan umum, mencerdaskan kehidupan bangsa dan ikut serta melaksanakan ketertiban dunia yang berdasarkan kemerdekaan, perdamaian abadi, dan keadilan sosial sebagaimana tertuang dalam pembukaan UUD NRI 1945. Negara bertujuan melindungi rakyat dan memajukan kesejahteraan umum serta keadilan sosial bagi seluruh rakyat Indonesia.

Momentum MEA 2015 yang telah disepakati oleh Pemerintah Indonesia memberikan konsekuensi kepada bangsa Indonesia sebagai bagian dari ASEAN untuk menyesuaikan diri dan tanggap dalam menghadapi berbagai bentuk ancaman, tantangan, dan peluang baru melalui transformasi ASEAN dari suatu Asosiasi menjadi Komunitas ASEAN berdasarkan Piagam ASEAN. Jumlah penduduk Indonesia yang sangat besar dibanding negara ASEAN lainnya harus dijadikan sebagai peluang bukan malah menimbulkan kerugian bagi tenaga kerja domestik, menjadi penonton masuknya tenaga kerja asing dan menambah jumlah pengangguran angkatan kerja. Maka dari itu, Indonesia harus siap dalam menghadapi MEA 2015 atau pasar tunggal ASEAN. Kesiapan tersebut baik dari segi kualitas SDM maupun dari segi kesiapan hukum nasional sangat dibutuhkan. Sebagai negara hukum yang bercirikan negara hukum kesejahteraan (welfare state) pemerintah memegang peran penting dalam melindungi dan menjamin kesejahteraan rakyatnya melalui kebijakan yang mengakomodasi kepentingan rakyat demi tercapainya kesejahteraan rakyat yang dicitacitakan. Dengan berlakunya MEA di Tahun 2015 Indonesia harus siap menghadapi berbagai tantangan, kesiapan baik dari aspek kualitas SDM maupun kesiapan dari aspek hukum nasional untuk menghadapi persaingan global khususnya arus bebas tenaga kerja terampil.

Kualitas SDM merupakan hal yang sangat perlu untuk dikembangkan untuk meningkatkan daya saing bangsa menghadapi persaingan global khususnya MEA 2015. Menurut Robert J. Eaton, CEO Chrysler Corporation, Amerika Serikat: "The only we can beat the competition is with people", Eaton menegaskan bahwa di tengah-tengah pesatnya kecanggihan teknologi, peran SDM dalam menentukan keberhasilan perusahaan tidak bisa diabaikan, ibarat pepatah SDM merupakan sumber keunggulan kompetitif yang tak lekang oleh panas, tak lapuk oleh hujan. Hal ini berbeda dengan teknologi produk dan proses produksi yang dinilai semakin berkurang keampuhannya sebagai sumber keunggulan kompetitif. Kesuksesan pemasaran jasa sangat tergantung pada SDM yang dimiliki.

Peningkatan kualitas SDM baik angkatan kerja maupun pekerja dalam negeri harus dapat mendapatkan perhatian yang serius oleh pemerintah maupun pihak swasta agar dapat bersaing dengan tenaga kerja terampil (skilled labor) yang masuk dari luar negeri yang merupakan dampak diberlakukannya MEA 2015. Salah satu upaya yang perlu dilakukan yaitu, dengan menyiapkan kebijakan nasional yang mengarah kepada pengembangan dan 
peningkatan kualitas SDM tenaga kerja dalam mempersiapkan tenaga kerja terampil yang mampu bersaing dengan tenaga kerja terampil negara anggota ASEAN lainnya.

Peningkatan kualitas SDM tersebut harus didukung dengan kebijakan atau regulasi dari pemerintah. Undang-Undang Nomor 13 Tahun 2003 tentang Ketenagakerjaan (UU Tenaga Kerja) telah mengamanatkan peningkatan dan pengembangan kualitas sumber daya manusia melalui pelatihan kerja. Pemerintah dan swasta memegang peranan penting dalam menjalankan amanat dari UU Tenaga Kerja tersebut, dalam memberikan pelatihan kerja baik kepada calon tenaga kerja maupun pekerja/tenaga kerja yang telah bekerja sehingga dapat meningkatkan keterampilannya dan mampu bersaing menghadapi arus bebas tenaga kerja terampil di kawasan ASEAN. Selain itu pemerintah telah mengeluarkan Peraturan Pemerintah Nomor 23 Tahun 2004 tentang Badan Nasional Sertifikasi Profesi. Badan Nasional Sertifikasi Profesi (BNSP) mempunyai tugas melaksanakan sertifikasi kompetensi kerja. Dalam menjalankan tugasnya BNSP dapat memberikan lisensi kepada Lembaga Sertifikasi Profesi (LSP). Pemberian pelatihan dan sertifikasi profesi kepada tenaga kerja, baik pekerja maupun yang sedang mencari kerja merupakan hal yang sangat penting dilakukan oleh pemerintah maupun pihak swasta. Hal ini dalam rangka menghasilkan tenaga kerja yang terampil dan berkualitas serta memiliki kompetensi yang diakui baik nasional maupun internasional.

Pelaksanaan berbagai kebijakan yang telah ada di bidang ketenagakerjaan harus dioptimalisasi guna meningkatkan kualitas dan ataupengembangan SDM agar Indonesia mampu mempersiapkan tenaga kerja yang terampil dan berkompetensi yang mampu bersaing di tingkat global khususnya dalam menghadapi MEA 2015. Maka dari itu pelaksanaan UU Tenaga Kerja maupun Peraturan Pemerintah Nomor 23 Tahun 2004 harus dioptimalkan guna meningkatkan pelatihan kerja membentuk tenaga kerja terampil dan percepatan pembentukan lembaga sertifikasi profesi terutama di daerah agar tenaga kerja kita dapat siap dan mampu bersaing mebghadapi arus bebas tenaga kerja terampil menghadapi Masyarakat Ekonomi ASEAN 2015.

Berdasarkan latar belakang diatas menjadi penting untuk dibahas lebih jauh bagaimana kebijakan ketenagakerjaan di Indonesia serta bagaimanakah optimalisasi kebijakan ketenagakerjaan dalam mempersiapkan tenaga kerja terampil menghadapi menghadapi Masyarakat Ekonomi Asean 2015?

\section{B. Metode Penelitian}

Penelitian ini menggunakan metode penelitian hukum normatif, dimana sumber datanya diperoleh dari bahan kepustakaan atau data sekunder, yang terdiri dari dari bahan hukum primer, antara lain norma atau kaidah dasar, yaitu pembukaan UUD NRI Tahun 1945, Batang Tubuh UUD NRI 1945, dan peraturan perundangundangan sedangkan bahan hukum sekunder, antara lain buku-buku, hasil penelitian, serta pendapat pakar hukum. Data yang diperoleh akan dianalisis dengan metode deskriptif kualitatif.

\section{Pembahasan}

\section{Kebijakan Ketenagakerjaan di Indonesia}

Indonesia merupakan Negara hukum pancasila yang bercirikan Negara kesejahteraan 
sebagaimana dalam Alinea ke-4 Pembukaan UUD NRI 1945 menyatakan sebagai berikut:

"Kemudian daripada itu untuk membentuk suatu Pemerintah Negara Indonesia yang melindungi segenap bangsa Indonesia dan seluruh tumpah darah Indonesia dan untuk memajukan kesejahteraan umum, mencerdaskan kehidupan bangsa, dan ikut melaksanakan ketertiban dunia yang berdasarkan kemerdekaan, perdamaian abadi dan keadilan sosial...."

Alinea ke-4 Pembukaan UUD NRI 1945 di atas mengartikan bahwa, dengan diembannya tugas negara dalam menyelenggarakan kesejahteraan umum maka pembentukan berbagai peraturan di Negara Republik Indonesia menjadi sangat penting, peran negara dalam mengurusi kesejahteraan rakyat dalam bidang hukum, sosial, politik, ekonomi, budaya, lingkungan hidup, pertahanan keamanan serta mewujudkan keadilan sosial diselenggarakan melalui pembentukan peraturan-peraturan negara. Dalam negara kesejahteraan (welfare state/ verzorgingsstaat), tugas pemerintah tidak hanya terbatas untuk melaksanakan undang-undang yang telah dibuat oleh legislatif. Dalam persfektif welfare state, pemerintah dibebani kewajiban untuk menyelenggarakan kepentingan umum (bestuurszorg) atau mengupayakan kesejahteraan sosial, yang dalam menyelenggarakan kewajiban itu pemerintah diberi kewenangan untuk campur tangan (staatsbemoeienis) dalam kehidupan masyarakat, dalam batasbatas yang diperkenankan oleh hukum. Sehingga campur tangan pemerintah tersebut dapat dilaksanakan melalui kewenangan yang diberikan oleh undang-undang dalam mewujudkan kesejahteraan rakyat dalam bidang hukum, sosial, politik, ekonomi, budaya, lingkungan hidup, pertahanan keamanan serta mewujudkan keadilan sosial.
Berdasarkan ketentuan tersebut, dapat diketahui ada empat tujuan bernegara, yakni;

a. Protection function, negara melindungi seluruh tumpah darah Indonesia

b. Welfare function, negara wajib mewujudkan kesejahteraan bagi seluruh rakyat;

c. Educational function, negara memiliki kewajiban mencerdaskan kehidupan bangsa;

d. Peacefulness function, wajib menciptakan perdamaian dalam kehidupan bernegara dan bermasyarakat, baik ke dalam maupun ke luar.

Sehubungan dengan tujuan bernegara bangsa Indonesia, sebagaimana tercantum pada pembukaan UUD NRI 1945 tersebut, para pakar menyebutkan bahwa tujuan negara seperti itu mencerminkan tipe negara hukum kesejahteraan (welfare state). Teori negara hukum kesejahteraan merupakan perpaduan antara konsep negara hukum dan negara kesejahteraan. Negara hukum (rechstaat) ialah negara yang menempatkan hukum sebagai dasar kekuasaannya dan penyelenggaraan kekuasaan tersebut dalam segala bentuknya dilakukan di bawah kekuasaan hukum. Sedangkap konsep negara kesejahteraan adalah negara atau pemerintah tidak semata-mata sebagai penjaga keamanan atau ketertiban masyarakat, tetapi pemikul utama tanggung jawab mewujudkan keadilan sosial, kesejahteraan umum dan sebesar-besarnya kemakmuran rakyat.

Kesiapan Indonesia menghadapi tantangan globalisasi harus dipersiapkan dengan penguatan internal, kualitas sumber daya manusia yang mempunyai daya saing global harus ditingkatkan. Peran pemerintah dalam mempersiapkan hal tersebut sangatlah penting khususnya menghadapi pasar tunggal ASEAN 2015, sebagai kesepakatan untuk menjamin pembangunan berkelanjutan yang bermanfaat 
bagi generasi-generasi sekarang dan mendatang dan menempatkan kesejahteraan dan penghidupan yang layak serta kemakmuran rakyat sebagai pusat proses pembentukan komunitas ASEAN. Kerjasama regional tersebut memberikan peluang bagi Indonesia. Akan tetapi peluang tersebut dapat dimanfaatkan apabila Indonesia dapat memenuhi berbagai persyaratan-persyaratan termasuk kemampuan negara dalam mempersiapkan diri menghadapi persaingan pasar tunggal ASEAN. Bila Indonesia tidak siap menghadapi pasar tunggal tersebut, maka Indonesia dapat menjadi negara tujuan pemasaran bagi Negara ASEAN lainnya. Kemampuan untuk bersaing akan memburuk dan peluang pelaku usaha dalam negeri untuk bersaing ditingkat kawasan akan sangat kecil, seperti pelaku usaha kecil dan menengah.

Robert J. Eaton, CEO Chrysler Corporation, Amerika Serikat, mengemukakan: "The only we can beat the competition is with people", pernyataan Eaton menegaskan bahwa ditengahtengah pesatnya kecanggihan teknologi, ternyata peran SDM dalam menentukan keberhasilan perusahaan tidak bisa diabaikan, ibarat pepatah SDM merupakan sumber keunggulan kompetitif yang tak lekang oleh panas, tak lapuk oleh hujan. $\mathrm{Hal}$ ini berbeda dengan teknologi produk dan proses produksi yang dinilai semakin berkurang keampuhannya sebagai sumber keunggulan kompetitif. Kesuksesan pemasaran jasa sangat tergantung pada SDM yang dimiliki.

Peningkatan kualitas atau daya saing SDM merupakan langkah penting yang harus dilakukan oleh pemerintah terhadap tenaga kerja. Halini untuk dapat memanfaatkan peluang yang sebesar-besarnya dan dapat mengimbangi persaingan arus tenaga kerja terampil dari luar negeri. Maka dari itu, tenaga kerja Indonesia harus meningkatkan keterampilannya sesuai dengan MRA yang telah disetujui. Sehingga dapat memenuhi kebutuhan lapangan kerja dan dapat terserap di lapangan kerja digunakan baik di dalam negeri maupun di negara-negara ASEAN lainnya. Serta mengantisipasi lonjakan tenaga kerja terampil dari luar ke Indonesia. MRAs merupakan kesepakatan diantara dua pihak atau lebih untuk saling mengakui atau menerima beberapa atau keseluruhan. Adapun tujuan dari MRA adalah memfasilitasi perdagangan dan menstimulir aktifitas ekonomi antar berbagai pihak melalui keberterimaan kompetensi SDM dalam hal satu standar, satu pengujian, satu sertifikasi, dan apabila sesuai, satu penandaan.

Menurut Yusuf Suit-Almasdi, SDM adalah kekuatan daya fikir dan berkarya manusia yang masih tersimpan dalam dirinya yang perlu digali, dibina serta dikembangkan untuk dimanfaatkan sebaik-sebaiknya bagi kesejahteraan kehidupan manusia. SDM adalah kemampuan potensial yang dimiliki oleh manusia yang terdiri dari kemampuan berfikir, berkomunikasi, bertindak, dan bermoral untuk melaksanakan suatu kegiatan baik bersifat teknis maupun manajerial. Kemampuan yang dimiliki tersebut akan dapat mempengaruhi sikap dan perilaku manusia dalam mencapai tujuan hidup baik individual maupun bersama. SDM adalah semua potensi yang dimiliki oleh manusia yang dapat disumbangkan atau diberikan kepada masyarakat untuk menghasilkan barang atau jasa.

Unsur-unsur (variables) sumber daya manusia meliputi kemampuan-kemampuan (capabilities), sikap (attitudes), nilai-nilai (values), kebutuhan-kebutuhan (needs), dan karakteristik-karakteristik demografisnya (penduduk). Unsur-unsur SDM tersebut sangat dipengaruhi oleh lingkungan sekitarnya seperti 
norma-norma dan nilai-nilai masyarakat, tingkat pendidikan dan peluang-peluang yang tersedia.

Setiap tenaga kerja untuk memperoleh, meningkatkan atau mengembangkan kompetensi kerja sesuai dengan bakat, minat dan kemampuan melalui pelatihan kerja. Pengembangan adalah suatu usaha untuk meningkatkan kemampuan teknis, teoritis, konseptual, dan moral karyawan sesuai dengan kebutuhan pekerjaan/jabatan melalui pendidikan dan latihan. pendidikan meningkatkan keahlian teoritis, konseptual dan moral karyawan, sedangkan latihan bertujuan untuk meningkatkan keterampilan teknis pelaksanaan pekerjaan karyawan.

Latihan adalah bagian pendidikan yang menyangkut proses belajar untuk memperoleh dan meningkatkan keterampilan di luar sistem pendidikan yang berlaku dalam waktu yang relatif singkat dan dengan metode yang lebih mengutamakan praktik daripada teori. Jadi, pengembangan meliputi pendidikan dan latihan untuk meningkatkan keterampilan kerja baik teknis maupun managerial.

Pengusaha bertanggung jawab atas peningkatan dan pengembangan kompetensi pekerjanya melalui pelatihan kerja. Peningkatan dan pengembangan kompetensi diwajibkan bagi pengusaha, karena perusahaan yang akan memperoleh manfaat dari hasil kompetensi pekerja/buruh. Pasal 12 ayat (3) UU Tenaga Kerja, menjamin setiap pekerja/buruh untuk memiliki kesempatan yang sama untuk mengikuti pelatihan kerja sesuai dengan bidang tugasnya.

Menteri Perencanaan Pembangunan Nasional/Kepala Bappenas, Armida Alisjahbana mengungkapkan, "peningkatan kualitas tenaga kerja di Indonesia merupakan salah satu tantangan utama dalam mempersiapkan diri menghadapi MEA. Peningkatan kualitas tenaga kerja ini merupakan tanggung jawab semua pihak. Tidak hanya pemerintah, dunia usaha juga wajib meningkatkan kualitas pekerjanya ke depannya." Lebih lanjut menurut Armida Alisjahbana: “....tingkat pendidikan rata-ratanya karyawan itu lebih rendah ketimbang negaranegara ASEAN, Pelatihan dunia usaha harus ditingkatkan, hanya 5 (lima) persen karyawan di Indonesia yang mendapat pelatihan di kantor."

Hal tersebut menunjukkan minimnya pelatihan yang diberikan kepada tenaga kerja dalam negeri. Hal tersebut tentunya akan mempengaruhi tingkat keterampilan dan daya saing tenaga kerja dalam negeri dengan dari tenaga kerja terampil yang masuk ke Indonesia.

Tenaga kerja dalam Pasal 1 angka 2 UU Tenaga Kerja yaitu, "Tenaga kerja adalah setiap orang yang mampu melakukan pekerjaan guna menghasilkan barang dan/atau jasa baik untuk memenuhi kebutuhan sendiri maupun untuk masyarakat. Sedangkan pekerja/buruh dalam Pasal 1 angka 3 diartikan bahwa setiap orang yang bekerja dengan menerima upah atau imbalan dalam bentuk lain." Jadi dapatdisimpulkan bahwa pekerja merupakan tenaga kerja yang sudah bekerja yang dapat disebut pekerja atau buruh. Pengertian tenaga kerja menurut UU Tenaga Kerja sejalan dengan pengertian tenaga kerja menurut konsep ketenagakerjaan pada umumnya sebagaimana ditulis Payaman J. Simanjuntak bahwa tenaga kerja atau manpower adalah mencakup penduduk yang sudah atau sedang bekerja, yang sedang mencari kerja dan yang melakukan pekerjaan lain seperti sekolah dan mengurus rumah tangga. Jadi semata-mata dilihat dari batas umur untuk kepentingan sensus di Indonesia menggunakan batas umur minimum 15 tahun dan batas umur maksimum 55 tahun. Tenaga kerja kerja terdiri 
dari angkatan kerja dan bukan angkatan kerja. Kelompok bukan angkatan kerja adalah:

a. Mereka yang dalam studi;

b. Golongan yang mengurus rumah tangga;

c. Golongan penerima pendapatan yakni, mereka yang tidak melakukan aktivitas ekonomi tapi memperoleh pendapatan misalnya pensiun, penerima bunga deposito dan sejenisnya

\section{Gambar 1 : Subjek dan Objek Ketenagakerjaan}

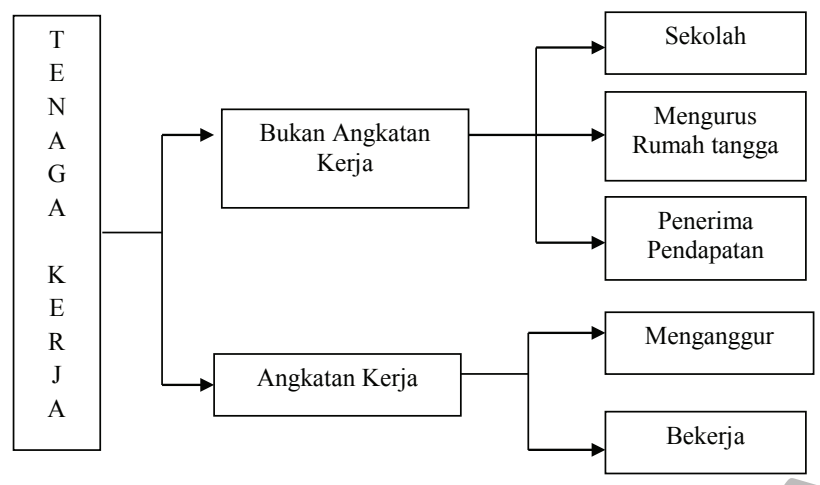

Sumber: Zaeni Asyhadie, Hukum Kerja: Hukum Ketenagakerjaan Bidang Hubungan Kerja, (Jakarta: PT RajaGrafindo Persada, 2007).

Bagan di atas mengelompokkan tenaga kerja yang terdiri atas angkatan kerja dan bukan angkatan kerja. Angkatan kerja terdiri dari menganggur atau yang sedang mencari kerja dan yang sedang bekerja. Sedangkan yang bukan angkatan kerja merupakan penduduk yang sedang melakukan pekerjaan lain dan tidak seperti, sekolah, mengurus rumah tangga, penerima pendapatan. Sedangkan Whimbo Pitoyo mengemukakan perbedaan tenaga kerja dan pekerja dikemukakan oleh sebagai berikut: ${ }^{1}$

a. Tenaga kerja adalah setiap orang yang melakukan pekerjaan, termasuk di dalamnya bekerja pada sektor informal, misalnya wiraswasta/pedagang yang bekerja untuk dirinya sendiri maupun orang lain.

b. Pekerja adalah mengarah pada bekerja untuk orang lain yang mendapatkan upah atau imbalan lain.

Menghadapi dampak yang akan ditimbulkan dari berlakunya MEA 2015 maka tenaga kerja baik yang meliputi angkatan kerja dan tenaga kerja atau yang sedang bekerja, perlu untuk meningkatkan keterampilan atau keunggulan kompetitif mereka agar tetap dapat bersaig dan diterima di dunia kerja. Peningkatan keterampilan (skills upgrading) merupakan tanggungjawab bersama baik pemeritah maupun pengusaha.

Dampak yang akan terjadi dalam berlakunya MEA 2015 adalah arus bebas tenaga kerja terampil antar negara, hal ini dalam rangka menciptakan liberalisasi jasa melalui pengurangan atau hambatan khususnya dalam mode 4 (movement of individual service providers) yaitu, tenaga kerja asing yang menyediakan keahlian tertentu dan datang ke negara konsumen. Pengertian tenaga kerja asing menurut Budiono yaitu, tenaga kerja asing adalah "tiap orang bukan warga negara Indonesia yang mampu melakukan pekerjaan, baik di dalam maupun di luar hubungan kerja, guna menghasilkan jasa atau barang untuk memenuhi kebutuhan masyarakat." Berdasarkan pengertian tersebut kendatipun orang tersebut bukan orang warga negara Indonesia dan berada di Indonesia, tetapi tidak bermaksud bekerja di wilayah Indonesia, maka

Whimbo Pitoyo, Panduan Praktis Hukum Ketenagakerjaan, (Jakarta: Visimedia, 2010), hlm. 4. 
dia bukanlah tenaga asing. ${ }^{2}$ Tenaga kerja asing dalam hal ini merupakan tenaga kerja terampil yang akan memberikan jasanya kepada negara konsumen sebagaimana standar yang telah disepakati dalam bentuk MRAs untuk berbagai bidang prioritas. Penggunaaan tenaga kerja asing tersebut harus menyesuaikan dengan ketentuan peraturan perundang-undangan yang berlaku di Indonesia.

Adapun berbagai peraturan perundangundangan yang mendukung peningkatan kualitas SDM/ tenaga kerja di Indonesia, sebagai berikut:

a. UUD NRI 1945.

b. Undang-Undang Nomor 13 Tahun 2003 tentang Ketenagakerjaan.

c. Undang-Undang Nomor 39 tahun 2004 tentang Penempatan dan Perlindungan Tenaga Kerja Indonesia di Luar Negeri.

d. Peraturan Pemerintah Republik Indonesia Nomor 23 Tahun 2004 tentang Badan Nasional Sertifikasi Profesi.

e. Peraturan Pemerintah Republik Indonesia Nomor 31 Tahun 2006 Tentang Sistem Pelatihan Kerja Nasional.

Pasal 28C ayat (1) UUD NRI 1945 menegaskan bahwa "setiap orang berhak mengembangkan diri melalui pemenuhan kebutuhan dasarnya, berhak mendapat pendidikan dan memperoleh manfaat dari ilmu pengetahuan dan teknologi, seni dan budaya, demi meningkatkan kualitas hidupnya dan demi kesejahteraan umat manusia." Dapat diketahui bahwa, UUD NRI 1945 menegaskan setiap orang berhak dalam mengembangkan diri, mendapatkan pendidikan demi meningkatkan kualitas dan kesejahteraan hidup. Hal ini sejalan dengan tujuan negara dalam mensejahterahkan rakyatnya. Termasuk di dalamnya tenaga kerja yang kita miliki, tenaga kerja lokal/domestik berhak untuk meningkatkan keterampilan atau kualitas hidupnya untuk mencapai kesejahteraan. Sehingga dapat bersaing dengan tenaga kerja terampil yang masuk ke Indonesia tanpa harus menjadi penonton atau pihak yang dirugikan di negeri sendiri. Sedangkan dalam UU Tenaga Kerja mengamanatkan untuk diberikannya pelatihan kerja kepada tenaga kerja. Pelatihan kerja diselenggarakan dan diarahkan untuk membekali, meningkatkan, dan mengembangkan kompetensi kerja guna meningkatkan kemampuan, produktivitas, dan kesejahteraan. Pelatihan kerja dilaksanakan dengan memperhatikan kebutuhan pasar kerja dan dunia usaha, baik di dalam maupun di luar hubungan kerja.

Tenaga kerja berhak memperoleh pengakuan kompetensi kerja setelah mengikuti pelatihan kerja yang diselenggarakan lembaga pelatihan kerja pemerintah, lembaga pelatihan kerja swasta, atau pelatihan di tempat kerja. Pengakuan kompetensi kerja dilakukan melalui sertifikasi kompetensi kerja. Sertifikasi kompetensi kerja sebagaimana dapat pula diikuti oleh tenaga kerja yang telah berpengalaman. Untuk melaksanakan sertifikasi kompetensi kerja dibentuk badan nasional sertifikasi profesi yang independen. Hal ini diatur dalam Pasal 18 UU Tenaga Kerja yang mengatur mengenai pemberian sertifikasi kompetensi kerja serta pembentukan BNSP. Ketentuan Pasal 20 ayat

\footnotetext{
Abdul Khakim, Dasar-Dasar Hukum Ketenagakerjaan Indonesia, (Bandung: PT Citra Aditya Bakti, 2009 ), hlm. 27.
} 
(1) dan (2) UU Tenaga Kerja mengamanatkan dikembangkannya satu sistem pelatihan kerja nasional yang merupakan acuan pelaksanaan pelatihan kerja di semua bidang dan/atau sektor untuk mendukung peningkatan pelatihan kerja dalam rangka pembangunan ketenagakerjaan. Ketentuan mengenai bentuk, mekanisme, dan kelembagaan sistem pelatihan kerja nasional tersebut ditindaklanjuti dengan Peraturan Pemerintah Nomor 31 Tahun 2006 tentang Sistem Pelatihan Kerja Nasional. Selain itu UU Tenaga Kerja mengamanatkan pembentukan BNSP dalam rangka memberikan sertifikasi kompetensi kerja bagi tenaga kerja. Sertifikasi kompetensi kerja merupakan proses pemberian sertifikat kompetensi yang dilakukan secara sistematis dan obyektif melalui uji kompetensi yang mengacu kepada standar kompetensi kerja nasional Indonesia dan/atau internasional.

\section{Optimalisasi Kebijakan Ketenaga- kerjaan Dalam Mempersiapkan Tenaga Kerja Terampil Menghadapi MEA 2015}

Pembentukan pasar tunggal ASEAN memiliki potensi untuk membuka peluang yang seluas-luasnya bagi Indonesia, apabila dapat mempersiapkan dengan sebaik-baiknya segala potensi yang ada seperti, luas wilayah, populasi dan SDM yang begitu besar, serta Sumber Daya Alam yang begitu melimpah dibandingkan negara lain yang ada di kawasan. Akan tetapi yang tidak kalah pentingnya dipersiapkan oleh Indonesia adalah mempersiapkan kualitas SDM. Tenaga kerja Indonesia harus dapat meningkatkan kompetensi atau keterampilan yang dimiliki sesuai dengan standar kompetensi atau MRAs yang telah disetujui. Perundingan liberalisasi sektor jasa menghasilkan empat cara penghilangan hambatan ketersediaan jasa dari penyedia jasa kepada pengguna jasa. Salah satu caranya adalah melalui mode ke-4 (keempat) berupa perpindahan fisik tenaga kerja (movement of natural persons) antar negara ASEAN yang akan diberlakukan untuk sektor prioritas. Indonesia harus dapat mempersiapkan sebaik mungkin dan meningkatkan kualitas tenaga kerjanya sehingga bisa digunakan baik di dalam negeri maupun di negara-negara kawasan ASEAN, untuk mencegah banjirnya tenaga kerja terampil dari luar. ${ }^{3}$

Berdasarkan hasil proyeksi Badan Pusat Statisitik Jumlah penduduk Indonesia pada Tahun 2013 sebanyak 248,8 juta orang. ${ }^{4}$ Jumlah angkatan kerja di Indonesia pada Februari 2014 mencapai 125,3 juta orang, bertambah sebanyak 5,2 juta orang dibanding angkatan kerja Agustus 2013 sebanyak 120,2 juta orang atau bertambah sebanyak 1,7 juta orang dibanding Februari 2013. Jumlah penduduk yang bekerja di Indonesia pada Februari 2014 mencapai 118,2 juta orang, bertambah sebanyak 5,4 juta orang dibanding keadaan pada Agustus 2013 sebanyak 112,8 juta orang atau bertambah 1,7 juta orang dibanding keadaan Februari 2013. ${ }^{5}$ Sedangkan jumlah pengangguran pada Februari 2014 mencapai 7,2 juta orang. ${ }^{6}$ Berdasarkan data BPS tersebut jumlah angkatan kerja di Indonesia yang mencapai 125,3 juta orang pada Februari 2014, Berdasarkan data

Op.Cit., R. Winantyo et al., 2008, hlm. 289.

Op.Cit., Laporan Bulanan Data Sosial Ekonomi 2014, hlm. 38.

Ibid., hlm. 45.

Ibid, hlm.48. 
tersebut diketahui bahwa jumlah penduduk dan angkatan kerja yang tinggi menjadikan arus bebas tenaga kerja merupakan peluang sekaligus tantangan bagi Indonesia dalam menghadapi MEA 2015. Peluang tersebut dapat digunakan oleh pemerintah dalam mengurangi pengangguran jika tenaga kerja lokal kita dapat bersaing dengan tenaga kerja terampil yang ada di kawasan ASEAN, Bahkan tenaga kerja kita dapat mencari peluang kerja di negara lain yang ada di kawasan ASEAN. Akan tetapi hal tersebut sekaligus menjadi tantangan bagi pemerintah maupun swasta apabila tenaga kerja kita tidak mampu bersaing dengan tenaga kerja asing atau tenaga kerja terampil yang masuk ke Indonesia dari negara ASEAN lainnya.

Peningkatkan pemberian pelatihan bagi tenaga kerja baik bagi pemerintah maupun pihak swasta/perusahaan baik dalam peningkatan keterampilan harus disesuaikan dengan standar kualifikasi atau MRAs yang telah disepakati oleh negara-negara anggota ASEAN. Salah satu bentuk nyata adalah optimalisasi kegiatan pelatihan kerja sebagaimana yang diamanatkan dalam Undang-Undang Nomor 13 Tahun 2003 tentang Ketenagakerjaan (UU Tenaga Kerja) untuk pengadaan pelatihan kerja guna meningkatkan kualitas SDM tenaga kerja Indonesia, hal tersebut diatur dalam Bab Kelima UU Tenaga Kerja terkait pemberian pelatihan kerja. Pentingnya pelatihan kerja adalah membekali, meningkatkan, mengembangkan seseorang dari yang belum mampu menjadi mampu untuk melaksanakan suatu pekerjaan sesuai persyaratan pekerjaan yang ditetapkan sehingga meningkat produktivitasnya yang pada akhirnya akan berdampak kepada penerimaan penghasilan untuk meningkatkan kesejahteraan dirinya maupun keluarganya. ${ }^{7}$

UU Tenaga kerja mengamanatkan pula dibentuknya BNSP melalui Peraturan Pemerintah Nomor 23 Tahun 2004 tentang Badan Nasional Sertifikasi Profesi. BNSP bersifat independen dan bertanggung jawab kepada presiden untuk melakukan sertifikasi kompetensi kerja. Berdasakan Pasal 4 Peraturan Pemerintah Nomor 23 Tahun 2004, guna terlaksananya tugas sertifikasi kompetensi kerja, BNSP dapat memberikan lisensi kepada Lembaga Sertifikasi Profesi (LSP) yang memenuhi persyaratan yang ditetapkan untuk melaksanakan sertifikasi kompetensi kerja. Sertifikasi kompetensi adalah proses pemberian sertifikasi kompetensi yang dilakukan secara sistematis dan obyektif melalui uji kompetensi yang mengacu pada standar kompetensi kerja baik yang bersifat nasional maupun internasional. ${ }^{8}$ Tujuan dari pemberian sertifikasi kompetensi kerja adalah untuk membantu secara formal para profesi, industri/ organisasi untuk memastikan dan memelihara kompetensi para tenaga kerja yang kompeten, serta membantu meyakinkan kliennya bahwa industri menggunakan tenaga yang kompeten. ${ }^{9}$ 
BNSP dan LSP pada dasarnya membantu industri/ pemakai jasa untuk meyakinkan bahwa mereka menggunakan tenaga kompeten serta penyiapan tenaga kerja Indonesia yang kompetitif menghadapi persaingan di pasar kerja global.

Maka dari itu, berbagai kebijakan dalam bidang ketenagakerjaan yang mendukung peningkatan kualitas SDM perlu dioptimalkan dalam pelaksanaannya. Mengingat pemberlakuan arus bebas tenaga kerja di tahun 2015 tidak akan lama lagi. Adapun berbagai kebijakan tersebut, diantaranya:

a. Undang-Undang Nomor 13 Tahun 2003 tentang Ketenagakerjaan;

b. Peraturan Pemerintah Republik Indonesia Nomor 23 Tahun 2004 tentang Badan Nasional Sertifikasi Profesi;

c. Peraturan Pemerintah Republik Indonesia Nomor 31 Tahun 2006 tentang Sistem Pelatihan Kerja Nasional;

d. Peraturan Presiden Republik Indonesia Nomor 8 Tahun 2012 tentang Kerangka Kualifikasi Nasional Indonesia

e. Peraturan Menteri Tenaga Kerja dan Transmigrasi Republik Indonesia Nomor 5 Tahun 2012 tentang Sistem Standardisasi Kompetensi Kerja Nasional

Berbagai kebijakan tesebut harus dapat dioptimalkan dalam pelaksanaannya seperti pemberian latihan kerja, sebaimana keterangan, Menteri Perencanaan Pembangunan Nasional/ Kepala Bappenas, hanya 5 (lima) persen karyawan di Indonesia yang mendapatkan pelatihan kerja. Hal ini tentunya turut mempengaruhi kualitas SDM dan keterampilan dari tenaga kerja nasional. Selain itu UU Tenaga Kerja telah mengamanatkan pembentukan BNSP yang dapat memberikan lisensi kepada Lembaga Sertifikasi Profesi (LSP) guna mempercepat pelaksanaan tugas BNSP dalam memberikan sertifikasi kompetensi di berbagai sektor. Hal ini harus mendapatkan perhatian yang serius bagi pemerintah maupun swasta. Hal ini merupakan tanggungjawab bersama pemerintah maupun swasta. Pengusaha memiliki kepentingan dalam meingkatkan keterampilan karyawannya sehingga kinerja karyawan dapat lebih terampil dan profesinal dalam menghasilkan barang dan jasa.

Kementerian Tenaga Kerja dan Transmigrasi merupakan Kementerian yang bertugas mewakili pemerintah dalam mewujudkan tenaga kerja dan masyarakat transmigrasi yang produktif, kompetitif dan sejahtera. Pelatihan Keterampilan Kerja merupakan program dari Badan Penelitian, Pengembangan dan Informasi Permasalahan Bidang Ketenagakerjaan Kementerian Tenaga Kerja dan Transmigrasi. Program tersebut berkaitan langsung dengan pengembangan sumber daya manusia (SDM), akan tetapi program tersebut belum mendapat posisi penting dalam pembangunan ketenagakerjaan nasional karena terdapat berbagai kendala. Adapun berbagai kendala dalam pemberian pelatihan maupun keterampilan kerja di Indonesia, sebagai berikut: ${ }^{10}$

a. Adanya duplikasi pelaksanaan pelatihan keterampilan kerja antara Kementerian Pendidikan dan Kebudayaan, dengan yang

10 Op.Cit., Badan Penelitian, Pengembangan dan Informasi Kementerian Tenaga Kerja dan Transmigrasi, hlm. 3941. 
dilaksanakan oleh Kementerian Tenaga Kerja dan Transmigrasi;

b. Belum adanya koordinasi yang integratif antara Kementerian/ Lembaga dan swasta yang melaksanakan pelatihan dengan Kementerian Tenaga Kerja dan Transmigrasi;

c. Belum kuatnya peraturan perundangundangan tentang pelatihan yang dilaksanakan oleh Kementerian Tenaga Kerja dan Transmigrasi karena hanya setingkat Peraturan Pemerintah (PP);

d. Belum memadainya anggaran pelatihan keterampilan kerja pada Kementerian Tenaga Kerja dan Transmigrasi;

e. Belum dijadikannya spesifikasi potensi wilayah sebagai dasar pelaksanaan pelatihan keterampilan kerja pada Balai Latihan Kerja Unit Pleksana Teknis Pusat (BLK UPTP) Kementerian Tenaga Kerja dan Transmigrasi, yang menyangkut kejuruan, peralatan dan bahan, instruktur, dan proporsi anggaran;

f. Sangat sedikitnya jumlah lulusan pelatihan keterampilan kerja yang dilaksanakan oleh BLK UPTP Kementerian Tenaga Kerja dan Transmigrasi bila dibandingkan dengan pencari kerja baru yang perlu dilatih;

g. Belum dapat diketahuinya dengan pasti berapa persen lulusan/pelatihan keterampilan kerja BLK UPTP Kementerian Tenaga Kerja dan Transmigrasi yang dapat bekerja dan/atau berusaha mandiri;

h. Kurangnya skill dan attitude kebanyakan lulusan BLK UPTP Kementerian Tenaga Kerja dan Transmigrasi, sehingga belum profesional dan belum dapat menjadi human capital;

i. Belum adanya keselarasan antara program pelatihan keterampilan kerja dengan program peningkatan produktivitas; j. Belum jelasnya konsep pelaksanaan pemagangan;

k. Terjadinya pelemahan fungsi lembaga pengembangan produktifitas daerah. Kebutuhan pelayanan pengembangan produktifitas di daerah masih relatif besar, namun tidak diikuti dengan peningkatan kapasitas pelayanan (lembaga, instruktur, metodologi);

I. Lumpuhnya sebagian besar BLK UPTD;

$\mathrm{m}$. Masih banyaknya perusahaan yang belum menganggap pelatihan keterampilan kerja bagi pekerja sebagai bagian dari investasi;

n. Masih banyaknya angkatan kerja yang belum memandang pelatihan keterampilan kerja sebagai kebutuhan;

o. Belum diakuinya secara internasional sertifikat kompetensi nasional;

Maka dari itu peran pemerintah maupun swasta sangat dibutuhkan dalam menyelesaikan persoalan-persoalan tersebut, seperti sinergi antar-lembaga, minimnya anggaran, kurangnya kesadaran angkatan kerja mengenai pentingnya keterampilan kerja, dan infrastruktur yang kurang memadai. Hal tersebut merupakan tanggung jawab bersama pemerintah dan swasta sehingga permasalahan tersebut dapat diselesaikan terutama pelatihan keterampilan kerja harus dapat dimaksimalkan dan menjadi harmonis antara sektor dan lembaga agar berbagai kendala dan hambatan tersebut dapat teratasi dalam mempersiapkan tenaga kerja terampil menghadapi berlakunya arus bebas tenaga kerja terampil 2015.

\section{PENUTUP}

Masyarakat Ekonomi ASEAN 2015 (MEA) atau ASEAN Economic Community 2015 merupakan integrasi ekonomi regional ASEAN 
dan salah satu pilar Komunitas ASEAN yang ditargetkan pencapaiannya pada Tahun 2015. Salah satu konsekuensi diberlakukannya MEA 2015 adanya arus bebas tenaga kerja terampil sebagaimana yang ditentukan dalam ASEAN Economic Blueprint atau Cetak Biru Masyarakat Ekonomi ASEAN. Cetak Biru Komunitas Ekonomi ASEAN tersebut ditindaklanjuti dengan Instruksi Presiden Republik Indonesia Nomor 11 Tahun 2011 tentang Pelaksanaan Komitmen Cetak Biru Masyarakat Ekonomi Association Of Southeast Asian Nations Tahun 2011. Konsekuensi dari arus bebas tenaga kerja terampil tersebut yaitu, tenaga kerja terampil di luar negeri dapat memberikan jasanya di Indonesia begitupula dengan tenaga kerja Indonesia dapat mencari pekerjaan di negara-negara ASEAN berdasarkan Mutual Recognition Arrangements (MRAs) yang merupakan kesepakatan mengenai standar kompetensi yang diakui oleh negara-negara anggota ASEAN.

Optimalisasi pelaksanaan kebijakan yang mendukung peningkatan kualitas tenaga kerja harus terus dilakukan baik pemerintah maupun swasta. Peningkatan kualitas tenaga kerja seperti pelatihan kerja di berbagai sektor baik oleh pemerintah maupun swasta, akan membantu Indonesia dalam mempersiapkan tenaga kerja terampil menghadapi MEA 2015. Sehingga pemerintah dapat memanfaatkan momentum tersebut dalam mengurangi pengangguran dengan ketersedian lapangan kerja di kawasan ASEAN. Kebijakan pemerintah yang mengamanatkan pengembangan SDM dalam mempersiapkan dan menghasilkan tenaga kerja terampil dan berkualitas menghadapi MEA 2015 sebenarnya telah ada, seperti di dalam UU Tenaga Kerja yang mengamanatkan diberikannya pelatihan kerja bagi tenaga kerja guna meningkatkan keterampilan dan kualitas hidupnya agar dapat mencapai kesejahteraan sebagaimana tujuan negara dalam Pembukaan UUD NRI 1945. Selain itu, UU Tenaga Kerja juga mengamanatkan pembentukan BNSP yang bertugas melakukan sertifikasi kompetensi profesi kepada tenaga kerja di berbagai sektor melalui LSP yang telah diberikan lisensi, agar tenaga kerja mendapat pengakuan kompetensi baik dalam lingkup nasional maupun internasional. Tahun 2015 merupakan tahun mulai diberlakukannya MEA, sudah sepatutnya pemerintah maupun pihak swasta intensif melakukan peningkatan keterampilan kepada para tenaga kerja serta mendorong peningkatan jumlah LSP guna melakukan percepatan sertifikasi kompetensi para tenaga kerja dan calon tenaga kerja dalam negeri.

\section{DAFTAR PUSTAKA}

\section{Buku}

Ardana, I Komang et al., Manajemen Sumber Daya Manusia (Yogyakarta: Graha Ilmu, 2012).

Asyhadie, Zaeni, Hukum Kerja: Hukum Ketenagakerjaan Bidang Hubungan Kerja, (Jakarta: PT Rajagrafindo Persada, 2007).

Amiruddin dan Zainal Asikin, Pengantar Metode Penelitian Hukum (Jakarta: Rajawali Pers, 2012).

Badan Penelitian, Pengembangan Dan Informasi Kementerian Tenaga Kerja dan Transmigrasi, Naskah Akademik Arah Kebijakan Ketenagakerjaan 2014-2019 (Jakarta: Puslibang Ketenagakerjaan, 2013).

Badan Pusat Statistik, Laporan Bulanan Data Sosial Ekonomi, (2014).

Cardoso Gomes, Faustino, Manajemen Sumber Daya Manusia, (Yogyakarta: Andi, 2003).

Husni, Lalu, Pengantar Hukum Ketenagakerjaan Indonesia, (Jakarta: PT Rajagrafindo Persada, 2009).

HR, Ridwan, Hukum Administrasi Negara (Jakarta: PT RajaGrafindo Persada, 2007).

Khakim, Abdul, Dasar-DasarHukum Ketenagakerjaan Indonesia, (Bandung: PT Citra Aditya Bakti, 2009). 
Lupiyoadi, Rambat dan A. Hamdani, Manajemen Pemasaran Jasa Edisi 2 (Jakarta: Salemba Empat, 2011).

Pitoyo, Whimbo, Panduan Praktis Hukum Ketenagakerjaan, (Jakarta: Visimedia, 2010)

Winantyo, R., et al., Masyarakat Ekonomi Asean (MEA) 2015: Memperkuat Sinergi ASEAN di Tengah Kompetisi Global (Jakarta: PT. Elex Media Komputindo, 2008).

Mulyanto, Djoko, Materi Presentasi Kompetensi Kerja Nasional Di Era Globalisasi, (Jakarta: Badan Nasional Sertifikasi Profesi).

\section{Makalah/Artikel/Hasil penelitian}

Asean Economic Community Blueprint (Cetak Biru Masyarakat Ekonomi ASEAN)

BNSPmenuju Indonesiayang Kompeten, http://ekbis. sindonews.com/read/2013/12/19/77/818761/ bnsp-menuju-indonesia-yang-kompeten, (diakses 11 Juni 2014).

Departemen Perdagangan Republik Indonesia, "Menuju ASEAN Economic Community 2015",http://ditjenkpi.kemendag.go.id/ website_kpi/Umum/Setditjen/Buku\%20 Menuju\%20ASEAN\%20ECONOMIC $\% 20$ COMMUNITY\%202015.pdf, (diakses 10 Mei 2014).

Direktorat Jenderal Kerjasama ASEAN Departemen Luar Negeri RI, 2009, "Cetak Biru Komunitas Ekonomi Asean (Asean Economic Community Blueprint)", http://www.smecda.com/Files/ Asean/Cetak\%20Biru\%20Komunitas\%20 Ekonomi\%20ASEAN.pdf. (diakses 9 Juni 2014).

Pemahaman Pasal-Pasal Utama Undang-Undang Ketenagakerjaan (UU NO. 13/2003), http://www. ilo.org/wcmsp5/groups/public/---asia/---robangkok/---ilo-jakarta/documents/publication/ wcms_120006.pdf, (diakses 4 Juni 2014).
Sertifikasi Kompetensi dan manfaatnya, http://www. iccosh-Iskk3.or.id/index.php/tentang-sertifikasikompetensi, (diakses 11 Juni 2014).

Sofie Widyana P., 2014 http://www. hukumtenagakerja.com/fungsi-pelatihan-kerja/, (diakses 5 Juni 2015).

Siti Nuraisyah Dewi dan R. Jihad Akbar, 2014, Hadapi MEA, "Dunia Usaha Minim Tingkatkan Kualitas Pekerja", http://idsaham.com/news-sahamHadapi-MEA-Dunia-Usaha-Minim-TingkatkanKualitas-Pekerja-409377.html, (diakses 2 Juni 2014).

\section{Peraturan}

Undang-Undang Dasar Negara Republik Indonesia Tahun 1945

Undang-Undang Nomor 13 Tahun 2003 tentang Ketenagakerjaan

Undang-Undang Nomor 39 tahun 2004 tentang Penempatan dan Perlindungan Tenaga Kerja Indonesia di Luar Negeri.

Undang-Undang No. 38 Tahun 2008 tentang Pengesahan Charter of The Association of Southeast Asian Nations (Piagam Perhimpunan Bangsa-Bangsa Asia Tenggara)

Peraturan Pemerintah Republik Indonesia Nomor 23 Tahun 2004 tentang Badan Nasional Sertifikasi Profesi

Peraturan Pemerintah Republik Indonesia Nomor 31 Tahun 2006 Tentang Sistem Pelatihan Kerja Nasional

Instruksi Presiden Republik Indonesia Nomor 11 Tahun 2011 tentang Pelaksanaan Komitmen Cetak Biru Masyarakat Ekonomi Association of Southeast Asian Nations Tahun 2011

Charter of The Association Of Southeast Asian Nation (Piagam ASEAN) 